\title{
URGENSI PENGUATAN PERAN PENUNTUT UMUM DALAM SISTEM PERADILAN PIDANA INDONESIA
}

\author{
Farid Achmad \\ Email : fafasyfa@gmail.com \\ Mahasiswa Magister Ilmu Hukum Universitas Sebelas Maret Surakarta \\ Supanto \\ Dosen Fakultas Hukum Universitas Sebelas Maret Surakarta
}

\begin{abstract}
The aim of this study is to know the urgency and the effort of strengthening the role of public prosecutor in criminal justice system in Indonesia. This study is a normative/doctrinal study using legislation approach and conceptual approach. The problem of this study is the reduction of the meaning and the function of Dominus Litis principle of public prosecutor by the effectuation of Kitab Undang-Undang Hukum Acara Pidana. The result of this study is the effort of strengthening the role of public prosecutor in criminal justice system in Indonesia; by maximizing the function of additonal investigation institution as been regulated in article 27 section (1) point $d U U$ no. 51991 and is maintained in UU No. 162004 [article 30 section (1) point e]. Besides, the improvement of law subtance is needed by adding the regulation about the active role of public prosecutor in doing investigation in criminal procedure law (KUHAP).
\end{abstract}

Keywords: criminal justice system, investigator, public prosecutor, strengthening.

\begin{abstract}
Abstrak
Penelitian ini bertujuan untuk mengetahui urgensi penguatan peran penuntut umum dalam Sistem Peradilan Pidana Indonesia dan untuk mengetahui bagaimana upaya penguatan peran penuntut umum dalam Sistem Peradilan Pidana Indonesia. Penelitian ini merupakan jenis penelitian normatif/doktrinal yang menggunakan metode pendekatan perundang-undangan dan pendekatan konseptual. Permasalahan dari penelitian ini adalah di reduksinya makna dan fungsi dari asas Dominus Litis dari penuntut umum dengan berlakunya Kitab Undang-Undang Hukum Acara Pidana. Hasil dari penelitian ini adalah upaya-upaya penguatan peran penuntut umum dalam Sistem Peradilan Pidana Indonesia berupa memaksimalkan fungsi lembaga pemeriksaan tambahan sebagaimana diatur dalam pasal 27 ayat (1) huruf d UU no. 5 tahun 1991 dan tetap dipertahankan dalam UU no.16 tahun 2004 pasal 30 ayat (1) huruf e. Selain itu, diperlukan penyempurnaan subtansi hukum dengan cara memasukkan ketentuan tentang peran aktif penuntut umum dalam tindakn penyidikan di dalam hukum acara pidana (KUHAP).
\end{abstract}

Kata Kunci: Sistem Peradilan, Penyidik, Penuntut umum, Penguatan.

\section{A. Pendahuluan}

Hukum adalah suatu sistem, yaitu sistem norma-norma, hukum pidana merupakan bagian dari sistem hukum atau sistem dari norma-norma, Sebagai sebuah sistem, hukum pidana memiliki sifat umum dari suatu sistem yaitu menyeluruh (wholes), memiliki beberapa elemen 
(elements) dan kemudian semua elemen tersebut saling terkait (relations) (Syaiful Bakhri, 2009: 20). Proses pengaturan mengenai hukum pidana diatur oleh negara sebagai puncak dari pengaturan hukum publik, yang mana untuk hukum pidana di Indonesia ada beberapa tahap yang harus dilalui dalam proses penyelesaiannya yang diatur dalam Undang-Undang nomor 8 tahun 1981 tentang Hukum acara Pidana Indonesia yang merupakan panduan dalam pelaksanaan berjalannya sistem Peradilan Pidana di Indonesia (Mahfud Mannan, 2012: 16). Dimana didalamnya diatur secara rinci dan sistematis pejabat atau lembaga yang berwenang melaksanakan sistem, beserta tugas dan kewenangannya masing-masing, Berdasarkan ketentuan yang diatur dalam KUHAP, sistem Peradilan Pidana Indonesia dijalankan oleh 4 (empat) komponen yaitu Kepolisian selaku penyidik, Kejaksaan sebagai Badan Penuntut Umum, Pengadilan bertugas mengadili dan memutus perkara serta lembaga pemasyarakatan melakukan pembinaan narapidana.

Kejaksaan Republik Indonesia merupakan lembaga yang diberi mandat untuk melaksanakan kekuasan negara dalam bidang penuntutan yang dilaksanakan oleh Penuntut Umum yang bila ditafsirkan secara etimologis berasal dari kata"prosecution" yang berasal daribahasa latin prosecutus, yang terdiri dari kata "pro"(sebelum) dan "sequi" (mengikuti). Mengacu pada pemaknaan kata"Penuntut Umum" secara etimologis dan dikaitkan dengan peran Kejaksaan dalam suatu sistem peradilan pidana, maka Kejaksaan seharusnya dipandang sebagai Dominus Litis (procuruer die de procesvoering vastselat) yaitu pengendali proses perkara dari tahapan awal penyidikan sampai dengan pelaksanaan proses eksekusi suatu putusan. Asas Dominus Litis ini merupakan hal yang universal sebagaimana terdapat dalam Pasal 11 Guidelines on the Role of Prosecutors yang juga diadopsi oleh Eight United Nation Congress on The Prevention of Crime dalam Kongres Pencegahan Kejahatan ke- 8 di Havana pada tahun 1990 dan di Indonesia juga telah eksplisit diakui dalam Putusan Mahkamah Konstitusi Nomor 55/PUU-X11/2013.

Namun nyatanya, asas Dominus Litis telah direduksi pemaknaannya dan fungsinya dengan berlakunya Kitab Undang-Undang Hukum Acara Pidana melalui prinsip diferensiasi fungsional yang mengakibatkan terkotak-kotaknya subsistem penyidikan dengan penuntutan. Sekalipun KUHAP tidak menerapkan fungsi penuntut umum sebagai Dominus Litis secara maksimal, Kejaksaan tetap diberi porsi terbatas untuk melakukan pengawasan secara horizontal terhadap proses penyidikan yang bertujuan agar tidak terjadi penyalahgunaan wewenang oleh aparat penegak hukum yang berpotensi melanggar hak asasi manusia.

Pelaksanaan pengawasan secara horizontal saat ini terwujud dalam lembaga prapenuntutan yang menjadi sarana kordinasi penuntut umum dengan penyidik. Akan tetapi, lembaga prapenuntutan terbukti tidak efektif mencapai tujuannya menjadi untuk menjadi sarana kordinasi fungsional, sekaligus pengawasan penuntut umum atas kinerja penyidik. Hal ini diantaranya diakibatkan oleh tidak maksimalnya pengaturan mengenai prapenuntutan dalam norma positif KUHAP. Jika merujuk pada ketentuan Pasal 14 huruf b KUHAP, prapenuntutan hanya dilakukan “apabila ada kekurangan pada penyidikan”, frase ini menandakan prapenuntutan seolah-olah bukan sebagai bagian integral dari sistem peradilan terpadu dan bukanlah suatu keharusan. Selain itu, Pasal 14 huruf b KUHAP juga tidak memposisikan penuntut umum untuk dapat berperan secara aktif dari awal tahapan penyidikan. Kondisi ini menyulitkan penuntut umum untuk dapat aktif menjaga nilai-nilai Due Process of law yaitu mencegah terjadinya suatu pelanggaran/kesewenang-wenangan 
yang dilakukan oleh penyidik terhadap tersangka (Choky R. Ramadan dkk., 2015) serta menjaga kualitas upaya penuntutan yang merupakan elemen penting dalam penyelesaian suatu perkara pidana, Akibatnya dalam penyelesaian perkara pidana banyak ditemui kasuskasus mengambang (floating case) sebagaimana yang ditulis oleh Prof Andi Hamzah pada Jurnal teropong MaPPI FHUI Volume 2-Oktober 2014, beliau mengatakan "Akibat dari adanya tahapan prapenuntutan atau adanya proses perkara mondar- mandir antara penyidik dan jaksa, maka dalam 10 tahun terakhir, terdapat 550.000 perkara hilang (Andi Hamzah, 2014). Hal ini dapat dilihat dari data perkara tindak pidana umum di seluruh Indonesia yang tidak ditindaklanjuti oleh penyidik selama kurun waktu 7 (tujuh) tahun dari tahun $2005 \mathrm{~s} / \mathrm{d}$ 2011, yaitu sebagai berikut :

Dalam kurun waktu tahun 2005-2011, sangat besar sekali, yaitu sebanyak 555. 110 (lima ratus lima puluh lima ribu seratus sepuluh) perkara. Dari jumlah tersebut, perkara yang SPDP-nya telah disampaikan ke jaksa namun tidak ada tindaklanjutnya sebanyak 467.786 (empat ratus enam puluh tujuh ribu tujuh ratus delapan puluh enam) perkara; perkara yang dikembalikan jaksa dengan petunjuk untuk dilengkapi (P-18/P-19) namun tidak dikembalikan lagi oleh penyidik sebanyak 41.274 (empat puluh satu ribu dua ratus tujuh puluh empat) perkara; dan perkara yang sudah dinyatakan lengkap (P-21) namun tidak diikuti dengan penyerahan tersangka dan barang bukti (tahap II) sebanyak 46.050 (empat puluh enam ribu lima puluh) perkara.

Selain adanya kasus-kasus mengambang, keterbatasan peran penuntut dalam KUHAP juga mengakibatkan beberapa putusan bebas yaitu

1. Putusan bebas Mahkamah Agung No. 936 K/Pid.Sus/2012 a.n Arief Hariyanto (pencabutan BAP, dikarenakan penyidik melakukan tekanan saat pemeriksaan)

2. Putusan bebas Mahkamah Agung No. 1875/K/Pid/2011 a.n Senali bin Nawar (pencabutan BAP, dikarenakan penyidik melakukan penyiksaan saat pemeriksaan)

3. Putusan bebas Mahkamah Agung No. 600/K/Pid/2009 a.n Rijan als Ijan (pencabutan BAP, dikarenakan penyidik melakukan penyiksaan saat pemeriksaan)

4. Putusab bebas Mahkamah Agung No. 2026/K/Pid/2011 a.n Toni bin Umar (pencabutan BAP, dikarenakan penyidik melakukan penyiksaan saat pemeriksaan)

Berdasarkan hal-hal tersebut diatas maka keterbatasan peran penuntut umum dalam penyelesaian perkara pidana yang diatur dalam KUHAP dapat menyebabkan ketidakpastian hukum termasuk terabaikannya hak-hak pencari keadilan, baik tersangka, korban maupun kepentingan umum, sehingga melahirkan beberapa pertanyaan-pertanyaan, Bagaimana keterbatasan peran penuntut umum dalam sistem peradilan pidana menurut KUHAP? Bagaimana upaya untuk memaksimalkan peran penuntut umum dalam sistem sistem peradilan pidana di Indonesia? Hal-hal ini lah yang akan dikaji dalam artikel ini.

\section{B. Metode Penelitian}

Pada penelitian ini penulis menggunakan jenis penelitian hukum normatif atau hukum kepustakaan, penelitian hukum normatif memiliki definisi yang sama dengan penelitian doktrinal (doctrinal research) yaitu penelitian berdasarkan bahan-bahan hum (library based) yang terfokus pada pembaca dan mpelajari bahan-bahan hukum primer sekunder (Jhonny 
Ibrahim, 2005: 44). menggunakan metode pendekatan perundang-undangan dan pendekatan konseptual. Metode yang digunakan dalam penelitian ini merupakan metode pendekatan perundang-undangan dan pendekatan konseptual.

\section{Hasil Penelitian dan Pembahasan}

\section{Urgensi penguatan peran penuntut umum dalam Sistem Peradilan Pidana Indonesia}

Sebagaimana telah dikemukakan sebelumnya, dengan terbatasnya peran penuntut umum dalam sistem berlakunya KUHAP ternyata ditemukan banyak floating case, seperti: perkara yang SPDP-nya dikirim ke kejaksaan tetapi tidak ditindaklanjuti dengan pengiriman berkas perkara; berkas perkara yang dikembalikan jaksa untuk dilengkapi namun tidak dikirim kembali oleh penyidik; dan berkas perkara yang sudah dinyatakan lengkap tetapi tidak diikuti dengan penyerahan tersangka dan barang bukti. Di sisi lain, hukum acara yang diatur dalam KUHAP tidak memberi jalan keluar atas penyelesaian kasus seperti itu, sehingga menimbulkan ketidakpastian dan dapat merugikan para pencari keadilan. Hal ini berbeda dengan Het Herziene Inlandsch Reglement/HIR (Staatsblad 1941 No. 44) yang menganggap penyidikan adalah bagian dari penuntutan sehingga selain sebagai penuntut umum, Jaksa juga diberi kewenangan melakukan penyidikan dan penyidikan lanjutan (Pasal 39 HIR). Dengan adanya kewenangan penyidikan dan penyidikan lanjutan, bila ada perkara yang tidak ditindaklanjuti penyidik, jaksa dapat mengambil alih perkara dan melakukan penyidikan sendiri.

Pada masa HIR Jaksa ditetapkan sebagai koordinator aparat penyidik yang disebut dengan Jaksa pembantu (hulp magistraat). HIR menganggap tugas penyidikan pada hakekatnya ialah membatu tugas penuntutan, yaitu membuktikan salah tidaknya terdakwa di pengadilan. Pembuktian ada di pengadilan dan yang ditugaskan untuk itu ialah Jaksa, maka Jaksa punya kewajiban mengendalikan, mengarahkan dan mengawasi jalannya penyidikan dalam pencarian dan pengumpulan alat bukti, oleh karenanya Jaksa ditetapkan sebagai koordinator penyidik. Adapun yang ditunjuk sebagai Jaksa pembantu ialah kepala distrik (wedana/asisten wedana), kepala onderdistrik (kepala desa), pegawai polisi umum yang sekurang-kurangnya berpangkat mantri polisi,dan pegawai polisi umum yang ditunjuk oleh Jaksa Agung [Pasal 51 ayat (1) HIR]. Tugas dan wewenang Jaksa pembantu ialah membantu jaksa dalam mengumpulkan alat bukti di lapangan, oleh karena itu wewenangnya dalam pengumpulan alat bukti ini sama dengan wewenang Jaksa, yaitu menerima pengaduan tentang kejahatan atau pelanggaran (Pasal 53 HIR). Setelah menerima pengaduan, Jaksa Pembantu melakukan pengusutan (penyidikan/ proses verbal) yang hasilnya segera dilaporkan kepada Jaksa untuk dilakukan penuntutan karena Jaksa Pembantu tidak mempunyai kewenangan melakukan penuntutan perkara pidana. Apabila jaksa telah melakukan sendiri penyidikan terhadap suatu perkara, maka untuk menangani perkara tersebut tidak diperlukan lagi penyidikan dari Jaksa Pembantu agar tidak terjadi duplikasi (Khuneiffi Alhufeffi, 2012: 3).

Kewenangan penyidikan dan penyidikan lanjutan yang dimiliki Jaksa, nampaknya kurang berkenan di pihak Kepolisian, sehingga berusaha menghilangkan kewenangan penyidikan dan penyidikan lanjutan yang dimiliki Jaksa. Upaya tersebut menyebabkan 
munculnya konflik antar aparat penegak hukum. Daniel S. Lev menyebut konflik tersebut sebagai pertikaian yang getir dalam sistem peradilan (judicial war) pidana Indonesia (Daniel S.Lev, 1990: 140). Menurut A.Z. Abidin lahirnya konflik diantara lembaga penegak hukum dipengaruhi oleh keberhasilan PKI menerapkan konsep pertentangan kelas. Pengadilan dipertentangkan dengan kejaksaan dan kejaksaan dibenturkan dengan kepolisian. Padahal tujuan dari konsep ini, bukan dimaksudkan untuk memperbaiki sistem peradilan pidana (criminal justice system), tetapi semata-mata memperebutkan status dan menuntut kesetaraan (A. Z. Abidin, 2004: 4).

Konflik itu akhirnya dimenangkan oleh polisi karena UU Pokok Kepolisian dan UU Pokok Kejaksaan Tahun 1961 menetapkan pihak pertama (polisi)-lah yang berwenang mengadakan penyidikan pendahuluan. Namun undang-undang itu juga mengandung ketentuan rangkap sebagi upaya membuat kompromi, dan memberi peluang dibuatnya saling pengertian mengenai pembagian kerja yang cocok yang tidak mengesampingkan penuntut umum dari pengusutan kejahatan (A. Z. Abidin, 2004: 141), Sebab dalam Undang-undang Kejaksaan Tahun 1961, jaksa masih diberi kewenangan melakukan penyidikan lanjutan sebagaimana diatur dalam Pasal 2 ayat (2) UU No. 15 Tahun 1961 yang berbunyi:

"untuk melaksanakan ketentuan-ketentuan dalam Pasal 1, kejaksaan mempunyai tugas mengadakan penyidikan lanjutan terhadap kejahatan dan pelanggaran serta mengkoordinasikan alat-alat penyidik menurut ketentuan dalam hukum acara pidana dan lain-lain peraturan negara. "

Dengan lahirnya UU Kejaksaan 1961 dan UU Kepolisian 1961, maka langkah pertama 'mengebiri' kewenangan jaksa telah berhasil dilakukan, walaupun hal itu justru mengaburkan hubungan antara magistraat dan hulp magistraat. Menurut Bismar Siregar aturan-aturan yang ada dalam kedua undang-undang tersebut hanya mengaburkan ketentuan dan sistem yang secara tegas dan jelas tertera dalam HIR di mana jaksa adalah magistraat dan polisi adalah hulp magistraat. Keraguan timbul umpamanya dalam wewenang penyidikan polisi yang seakan-akan telah menjadi otonom dan berdiri sendiri menurut Pasal 13 UU No. 13 Tahun 1961, sehingga mungkin dapat dikatakan bahwa ia bukan lagi hulp magistrate (Bismar Siregar, 1983: 91). Padahal menurut doktrin tugas pembuktian itu ada pada jaksa dan tugas penyidik membantu jaksa mencari dan mengumpulkan alat bukti yang berserakan di lapangan. Oleh karena itu, antara penyidikan dan penuntutan tidak bisa dipisah-pisahkan secara tajam dan jaksa seharusnya dapat menyidik semua tindak pidana jika mau. Artinya penyidikan seharusnya memang ditangan polisi, namun dalam keadaan tertentu, jaksa dapat melakukan penyidikan sendiri.

Perselisihan antara polisi dan jaksa ternyata terus berlanjut pada saat penyusunan peraturan tentang hukum acara pidana untuk menggantikan HIR. Polisi masih menginginkan agar semua kewenangan jaksa yang terkait dengan penyidikan dihapuskan. Akhirnya Judicial War II terjadi pada saat penyusunan UU No. 8 Tahun 1981 Perselisihan tersebut kembali dimenangkan polisi dengan dihapuskannya kewenangan jaksa untuk melakukan penyidikan lanjutan dan menjadi koordinator penyidik. Semua kewenangan tersebut kemudian dialihkan ke polisi dan Jaksa hanya ditetapkan sebagai penuntut umum kecuali untuk tindak pidana tertentu. 
Saat KUHAP disahkan, pucuk pimpinan 3 (tiga) institusi penegak hukum berasal dari kalangan militer yang masih aktif, dan saat itu kepolisian masih menjadi bagian dari militer (ABRI). Ketua Mahkamah Agung dijabat Moedjono; Ali Said sebagai Menteri Kehakiman; dan Jaksa Agung-nya Ismael Saleh. Menurut Andi Hamzah, hilangnya kewenangan penyidikan oleh jaksa, tidak lepas dari peranan Jaksa Agung yang saat itu dijabat militer. Setelah Jaksa Agung bersal dari militer, dengan mudah Panglima ABRI memanggil Jaksa Agung dan dengan mudah pula Jaksa Agung diminta melepaskan wewenang penyidikan dalam KUHAP (Hari Sasangka, 2007: 156-157). Hilangnya kedudukan jaksa sebagai penyidik dan koordinator penyidik menyebabkan banyak perkara mengambang karena tidak ditindaklanjuti oleh penyidik, sedangkan jaksa juga tidak bisa melakukan penyidikan sendiri. Banyaknya floating case tersebut dapat dipisahkan menjadi 3 (tiga) macam kategori yaitu :

a. Perkara yang sudah dinyatakan lengkap, tetapi belum diserahkan tersangka dan barang buktinya.

b. Permintaan penyempurnaan berkas penyidikan dalam rangka prapenuntutan oleh jaksa, namun tidak ditindaklanjuti oleh penyidik; dan

c. Perkara yang sudah ada Surat Pemberitahuan dimulainya penyidikan (SPDP) atau SPDP-nya sudah diterima jaksa tetapi berkasnya belum dilimpahkan

Selain itu hilangnya kewenangan Jaksa sebagai penuntut umum dalam melakukan peran aktif penyidikan juga membuat posisi Jaksa menjadi lemah dan tidak meyakinkan di persidangan karena Jaksa tidak dapat mengetahui jalannya penyidikan secara obyektif dan substansial dan hanya memeriksa berkas perkara dari penyidik, kemudian dari hasil penyidikan tersebut Jaksa membuat surat dakwaan yang "hanya" berasal dari pekerjaan Penyidik dalam proses penyidikan.

Surat dakwaan itu sendiri yaitu suatu surat atau akta yang memuat rumusan tindak pidana yang didakwakan kepada terdakwa yang disimpulkan dan ditarik dari hasil pemeriksaan Penyidikan dan merupakan dasar serta landasan bagi hakim dalam pemeriksaan di muka pengadilan membawa konsekuensi bahwa rumusan surat dakwaan harus sejalan dengan hasil pemeriksaan penyidikan. Rumusan surat dakwaan yang menyimpang dari hasi pemeriksaan penyidikan merupakan surat dakwaan yang palsu dan tidak benar. Surat dakwaan yang demikian tidak dapat dipergunakan jaksa menuntut terdakwa (M. Yahy Harahap, 2003: 391) dengan pengertian tersebut dapat disimpulkan bahwa segala sesuatu yang tertera dalam surat dakwaan penuntut umum merupakan segala sesuatu yang terjadi dituangkan dalam berkas perkara yang merupakan hasil penyidikan, Namun demikian ada beberapa hal didalam KUHAP, karena dibatasinya peran penuntut umum berpotensi menimbulkan permasalahan bagi penuntut umum dalam proses penuntutan yang merupakan bagian penting dalam proses penyelesaian suatu perkara pidana.

Dalam pasal 183 KUHAP dijelaskan bahwa : "Hakim tidak boleh menjatuhkan pidana kepada seorang kecuali apabila sekurang-kurangnya dua alat bukti yang sah ia memperoleh keyakinan bahwa suatu tindak pidana benar-benar terjadi dan bahwa terdakwalah yang bersalah melakukannya " (UU nomor 8 tahun 1981). 
Kemudian pasal 184 KUHAP menjelaskan :

1) Alat bukti yang sah ialah :

a Keterangan saksi ;

b Keterangan ahli ;

c Surat

d Petunjuk ;

e Keterangan terdakwa.

Bahwa yang dimaksud dengan masing-masing alat bukti tersebut dibahas dalam ketentuan-ketentuan setelahnya.

Pasal 185 ayat (1) KUHAP menjelaskan: "Keterangan saksi sebagai alat bukti ialah apa yang saksi nyatakan di sidang Pengadilan"

Kemudian mengenai keterangan ahli dibahas dalam pasal 186 KUHAP, yang menjelaskan, bahwa keterangan ahli ialah apa yang seorang ahli nyatakan di sidang Pengadilan. Sedangkan apa yang dimaksud dengan surat diatur dalam pasal 187 KUHAP. Berikutnya mengenai ketentuan yang membahas petunjuk diatur dalam pasal 188 ayat (1) KUHAP,: "Petunjuk adalah perbuatan, kejadian atau keadaan, yang karena persesuaiannya, bai antara satu dengan yang lain, maupun dengan tindak pidana itu sendiri, menandakan bahwa telah terjadi suatu tindak pidana dan siapa pelakunya ", Dalam pasal 188 ayat (3) KUHAP menjelaskan: " Penilaian atas kekuatan pembuktian dari suatu petunjuk dalam sebuah keadaan tertentu dilakukan oleh hakim dengan arif lagi bijaksana setelah ia mengadakan pemeriksaan dengan penuh kecermatan dan kesaksamaan berdasarkan hati nuraninya.

Alat bukti yang terakhir adalah keterangan terdakwa, yang berbunyi : "Keterangan terdakwa ialah apa yang terdakwa nyatakan di sidang tentang perbuatan yang ia lakukan atau yang dia ketahui sendiri atau alami sendiri “

Berdasarkan terjemahan dan makna alat bukti sebagaimana dalam KUHAP diatas, maka dapat diketahui bahwa alat bukti yang digunakan hakim dalam memutus sebuah perkara pidana lebih dominan tentang sesuatu yang terjadi di persidangan. Hal ini menimbulkan kesan bahwa menentukan orang salah atau tidak ditentukan oleh apa yang terjadi di sidang pengadilan. Padahal penuntut umum dalam hal ini menyusun surat dakwaan yang dijadikan dasar pemeriksaan "hanya" berdasarkan hasil penyidikan. Dalam hal ini terkotak-kotaknya fungsi penyidikan, penuntutan dan pemeriksaan persidangan menimbulkan kesulitan tersendiri bagi penuntut umum untuk membuktikan dakwaannya. Bagaimana mungkin jaksa yang hanya membaca berkas perkara hasil penyidikan, tanpa pernah terjun langsung dalam penyidikan, tanpa pernah bertemu dengan saksi, tanpa pernah bertemu dengan ahli, tanpa pernah melihat surat, memeriksa terdakwa ataupun melihat barang bukti yang digunakan harus membuktikan surat dakwaannya yang disusun berdasarkan sesuatu yang belum diketahui secara pasti oleh penuntut umum. Maka tidak lah heran apabila dikalangan penuntut umum ada anekdot: "Jaksa Indonesia adalah Jaksa sakti, karena kebanyakan bisa membuktikan surat dakwaannya yang disusun berdasarkan hasil penyidikan yang belum pasti diketahui apa yang berada di dalam hasil penyidikan tersebut". 
Berdasarkan pengalaman penulis sebagai penuntut umum banyak menemukan realita bahwa apa yang terjadi dalam proses penyidikan (Berkas Perkara) belum tentu sama dengan apa yang terjadi di depan persidangan, misalnya keterangan saksi yang sangat berbeda dari yang terdapat dalam BAP penyidikan dengan apa yang saksi terangkan dalam proses persidangan, kemudian saksi yang dalam BAP menerangkan sesuatu kronologis peristiwa dengan runut dan jelas ternyata di dalam persidangan tidak tahu menahu akan peristiwa pidana yang terjadi, selain itu ada juga saksi yang dalam BAP menerangkan dengan jelas ternyata tidak mampu berbicara bahasa Indonesia bahkan saksi yang bersangkutan tidak dapat membaca dan menulis, dan masih banyak kejadian lain yang menunjukkan bahwa penuntut umum sendiri tidak mengetahui sejauh mana "kekuatan" surat dakwaan yang disusunnya. Apabila diibaratkan penuntut umum berada ditengah-tengah medan pertempuran dengan surat dakwaan sebagai senjatanya dengan berisi peluru-peluru fakta dalam penyidikan, maka kualitas peluru tersebut sangat menentukan keberhasilan pertempuran, dan karena permasalahan tersebut dapat mengakibatkan gagalnya proses penuntutan yang ditandai dengan adanya beberapa putusan yang bebas yaitu

1. Putusan bebas Mahkamah Agung No. 936 K/Pid.Sus/2012 a.n Arief Hariyanto (pencabutan BAP, dikarenakan penyidik melakukan tekanan saat pemeriksaan)

2. Putusan bebas Mahkamah Agung No. 1875/K/Pid/2011 a.n Senali bin Nawar (pencabutan BAP, dikarenakan penyidik melakukan penyiksaan saat pemeriksaan)

3. Putusan bebas Mahkamah Agung No. 600/K/Pid/2009 a.n Rijan als Ijan (pencabutan BAP, dikarenakan penyidik melakukan penyiksaan saat pemeriksaan)

4. Putusab bebas Mahkamah Agung No. 2026/K/Pid/2011 a.n Toni bin Umar (pencabutan BAP, dikarenakan penyidik melakukan penyiksaan saat pemeriksaan)

\section{Upaya penguatan peran Penuntut Umum dalam Sistem Peradilan Pidana Indonesia}

\section{a. Memaksimalkan mekanisme pemeriksaan tambahan.}

Untuk mendukung tugas Jaksa dalam melakukan pembuktian di persidangan, Jaksa diberi wewenang melakukan penelitian berkas hasil penyidikan. Bila dalam penelitiannya, ditemukan kekurangan baik formil maupun materiil, Jaksa berwenang memberi petunjuk demi kesempurnaan penyidikan. Hal ini dalam praktek peradilan disebut dengan prapenuntutan yang penyebutan istilahnya hanya ada dalam satu ketentuan, yaitu Pasal 14 huruf b KUHAP. Walaupun istilah prapenuntutan hanya terdapat dalam satu pasal, namun mekanismenya diatur dalam Pasal 110 dan Pasal 138 KUHAP, yang berbunyi sebagai berikut:

1) Pasal 110 KUHAP

(1) Dalam hal penyidik telah selesai melakukan penyidikan, penyidik wajib segera menyerahkan berkas perkara itu kepada penuntut umum.

(2) Dalam hal penuntut umum berpendapat bahwa hasil penyidikan tersebut ternyata masih kurang lengkap, penuntut umum segera mengembalikan berkas perkara itu kepada penyidik disertai petunjuk untuk dilengkapi.

(3) Dalam hal penuntut umum mengembalikan hasil penyidikan untuk dilengkapi, penyidik wajib segera melakukan penyidikan tambahan sesuai dengan petunjuk dari penuntut umum. 
(4) Penyidikan dianggap telah selesai apabila dalam waktu empat belas hari penuntut umum tidak mengembalikan hasil penyidikan atau apabila sebelum batas waktu tersebut berakhir telah ada pemberitahuan tentang hal itu dari penuntut umum kepada penyidik.

2) Pasal 138 KUHAP

(1) Penuntut umum setelah menerima hasil penyidikan dari penyidik segera mempelajari dan menelitinya dan dalam waktu tujuh hari wajib memberitahukan kepada penyidik apakah hasil penyidikan itu sudah lengkap atau belum.

(2) Dalam hal hasil penyidikan ternyata belum lengkap, penuntut umummengembalikan berkas perkara kepada penyidik disertai petunjuk tentang hal yang harus dilakukan untuk dilengkapi dan dalam waktu empat belas hari sejak tanggal penerimaan berkas, penyidik harus sudah menyampaikan kembali berkas perkara itu kepada penuntut umum.

Maksud dari diadakannya prapenuntutan ialah agar upaya penuntutan yang dilakukan jaksa tidak mengalami kegagalan karena lemahnya alat bukti yang diajukan ke pengadilan, atau karena adanya kesalahan-kesalahan lainnya. Hal ini sebagai jalan tengah atas dihilangkannya kedudukan Jaksa sebagai penyidik dan koordinator penyidik yang dulu diatur dalam HIR. Dalam kenyataannya, lembaga prapenuntutan tidak selalu berjalan efektif dalam mendukung kegiatan penuntutan yang dilakukan oleh Jaksa. Banyak berkas perkara yang dikembalikan Jaksa disertai petunjuk untuk dilengkapi, ternyata tidak dikembalikan penyidik kepada Jaksa, sehingga perkara tersebut tidak dapat diajukan ke penuntutan oleh Jaksa. Selain itu, lembaga prapenuntutan juga tidak dapat menyelesaikan perkara-perkara yang sudah dinyatakan lengkap, tetapi tidak diikuti penyerahan tersangka dan barang bukti, serta tidak bisa mengatasi masalah perkara yang SPDP-nya sudah diterima Jaksa tetapi berkasnya tidak dilimpahkan oleh penyidik.

Untuk menyelesaikan permasalahan perkara-perkara mengambang tersebut, akhirnya dibentuklah lembaga pemeriksaan tambahan sebagaimana diatur dalam Pasal 27 ayat (1) huruf d UU No. 5 Tahun 1991 dan tetap dipertahankan dalam UU No. 16 Tahun 2004 [Pasal 30 ayat (1) huruf e]. Rumusan norma dalam kedua ketentuan tersebut memiliki redaksional yang sama, yaitu:

"dalam perkara pidana kejaksaan mempunyai tugas dan wewenang melengkapi berkas perkara tertentu dan untuk itu dapat melakukan pemeriksaan tambahan sebelum dilimpahkan ke pengadilan yang dalam pelaksanaannya dikoordinasikan dengan penyidik”.

Kedua undang-undang tersebut, dengan tegas memberikan wewenang kepada Jaksa untuk melakukan pemeriksaan tambahan apabila hasil penyidikan penyidik belum lengkap, sehingga jaksa akan melengkapi sendiri berkas perkara itu dengan melakukan pemeriksaan tambahan. Namun dalam prakteknya, kewenangan tersebut tidak serta merta dapat dapat dilakukan oleh jaksa, karena dalam Penjelasan Pasal 27 ayat (1) huruf d UU No. 5 Tahun 1991 dan Penjelasan Pasal 30 ayat (1) huruf e UU No. 16 Tahun 2004 memuat syarat-syarat yang harus diperhatikan dalam melakukan pemeriksaan tambahan, yaitu: 
a. Tidak dilakukan terhadap tersangka;

b. Hanya terhadap perkara-perkara yang sulit pembuktiannya, dan/atau dapat meresahkan masyarakat, dan/atau yang dapat membahayakan keselamatan negara;

c. Harus dapat diselesaikan dalam waktu 14 hari setelah dilaksanakannya ketentuan Pasal 110 dan Pasal 138 ayat (2) KUHAP; dan

d. Prinsip koordinasi dan kerjasama dengan penyidik.

Berbagai syarat di atas, justru menjadi kendala dalam pelaksanaan pemeriksaan tambahan, sehingga kewenangan ini hampir tidak pernah dijalankan oleh Jaksa sebagai Penuntut umum dan Kejaksaan itu sendiri. Diantara ke-empat syarat di atas, prinsip koordinasi dan kerjasama dengan penyidik, menjadi kendala paling utama karena prinsip ini diartikan Jaksa baru bisa melakukan pemeriksaan tambahan setelah ada pernyataan optimal dari penyidik dan penyidik melimpahkan berkas hasil penyidikannya ke Jaksa. Tanpa adanya pelimpahan dari penyidik, Jaksa tidak dapat melengkapi berkas hasil penyidikan secara sepihak. Di sisi lain, penyidik hampir tidak pernah menyatakan optimal, sehingga Jaksa tidak bisa melakukan pemeriksaan tambahan karena Jaksa tidak diberi kewenangan mengambil alih penanganan perkara bila penyidik tidak menyatakan optimal. Kemudian syarat pemeriksaan tambahan harus dapat diselesaikan dalam batas waktu 14 (empat belas) hari juga sangat menyulitkan Jaksa karena terlalu singkat waktunya. Padahal perkaraperkara yang dapat dilakukan pemeriksaan tambahan adalah perkara-perkara yang sulit pembuktiannya. Oleh karena itu, jangka waktu 14 (empat belas) hari sangat sulit dipenuhi oleh Jaksa. Selain itu, adanya ketentuan yang melarang pemeriksaan tambahan dilakukan terhadap tersangka juga menyulitkan Jaksa, karena bila ternyata dalam pemeriksaan ditemukan adanya saksi yang berpotensi menjadi tersangka, maka Jaksa tidak bisa melakukan pemeriksaan. Padahal dalam rangka menemukan kebenaran materiil Jaksa juga perlu melakukan konfrontasi antara saksi dengan tersangka bila keduanya memberikan keterangan yang berbeda.

Lembaga pemeriksaan tambahan pertama kali diatur dalam UU Kejaksaan Tahun 1991. Hal ini berarti, eksistensi lembaga pemeriksaan tambahan dalam sistem peradilan pidana Indonesia sudah berlangsung kurang lebih selama 20 (dua puluh ) tahun. Namun selama kurun waktu tersebut, Jaksa sebagai penuntut umum sangat jarang sekali melakukan pemeriksaan tambahan untuk melengkapi berkas perkara dikarenakan adanya berbagai hambatan, sebagaimana telah dikemukan diatas, namun demikian sebagaimana dalam dalam Penjelasan Pasal 27 ayat (1) huruf d UU No. 5 Tahun 1991 dan Penjelasan Pasal 30 ayat (1) huruf e UU No. 16 Tahun 2004 tentang Kejaksaan Republik Indonesia bahwa ada hal yang harus diperhatikan yaitu adanya Prinsip koordinasi dan kerjasama dengan penyidik dalam hal pemeriksaan tambahan dan hal itu sangat diharapkan sebagai jalan keluar dari permasalahan yang dihadapi dalam pelaksanaan pemeriksaan tambahan.

\section{b Melakukan revisi KUHAP dalam hal pengaturan tentang peran aktif Jaksa dalam Penyidikan}

Lawrence M. Friedman mengemukakan bahwa efektif dan berhasil tidaknya penegakan hukum tergantung tiga unsur sistem hukum, yakni struktur hukum 
(struktur of law), substansi hukum (substance of the law) dan budaya hukum (legal culture). Struktur hukum menyangkut aparat penegak hukum, substansi hukum meliputi perangkat perundang-undangan dan budaya hukum merupakan hukum yang hidup (living law) yang dianut dalam suatu masyarakat.

Tentang struktur hukum Friedman menjelaskan (Lawrence M. Friedman, 1984: 5-6): "To begin with, the legal sytem has the structure of a legal system consist of elements of this kind: the number and size of courts; their jurisdiction ...Strukture also means how the legislature is organized ... what procedures the police department follow, and so on. Strukture, in way, is a kind of crosss section of the legal system... a kind of still photograph, with freezes the action."

Struktur dari sistem hukum terdiri atas unsur berikut ini, jumlah dan ukuran pengadilan, yurisdiksinnya (termasuk jenis kasus yang berwenang mereka periksa), dan tata cara naik banding dari pengadilan ke pengadilan lainnya. Struktur juga berarti bagaimana badan legislative ditata, apa yang boleh dan tidak boleh dilakukan oleh presiden, prosedur ada yang diikuti oleh kepolisian dan sebagainya. Jadi struktur (legal struktur) terdiri dari lembaga hukum yang ada dimaksudkan untuk menjalankan perangkat hukum yang ada.

Struktur adalah Pola yang menunjukkan tentang bagaimana hukum dijalankan menurut ketentuan-ketentuan formalnya. Struktur ini menunjukkan bagaimana pengadilan, pembuat hukum dan badan serta proses hukum itu berjalan dan dijalankan. Di Indonesia misalnya jika kita berbicara tentang struktur sistem hukum Indonesia, maka termasuk di dalamnya struktur institusi-institusi penegakan hukum seperti kepolisian, kejaksaan dan pengadilan (Achmad Ali, 2002 : 8).

Substansi hukum menurut Friedman adalah (Lawrence M. Friedman, Op.cit): "Another aspect of the legal system is its substance. By this is meant the actual rules, norm, and behavioral patterns of people inside the system ...the stress here is on living law, not just rules in law books".

Aspek lain dari sistem hukum adalah substansinya. Yang dimaksud dengan substansinya adalah aturan, norma, dan pola perilaku nyata manusia yang berada dalam system itu. Jadi substansi hukum menyangkut peraturan perundang-undangan yang berlaku yang memiliki kekuatan yang mengikat dan menjadi pedoman bagi aparat penegak hukum.

Sedangkan mengenai budaya hukum, Friedman berpendapat: "The third component of legal system, of legal culture. By this we mean people's attitudes toward law and legal system their belief ... in other word, is the climinate of social thought and social force wicch determines how law is used, avoided, or abused".

Kultur hukum menyangkut budaya hukum yang merupakan sikap manusia (termasuk budaya hukum aparat penegak hukumnya) terhadap hukum dan sistem hukum. Sebaik apapun penataan struktur hukum untuk menjalankan aturan hukum yang ditetapkan dan sebaik apapun kualitas substansi hukum yang dibuat tanpa didukung budaya hukum oleh orang-orang yang terlibat dalam sistem dan masyarakat maka penegakan hukum tidak akan berjalan secara efektif (www.dandreas.blogspot. co.id: 2017). 
Berdasarkan Teori Friedman tersebut diatas maka Alternatif lain untuk menyelesaikan terjadinya kasus-kasus mengambang dan dalam rangka pencapaian kesuksesan penuntutan penuntut umum adalah penyempurnaan substansi hukum dengan cara memasukkan ketentuan tentang peran aktif penuntut umum dalam tindakan penyidikan dalam hukum acara pidana (KUHAP) dan dalam UU Kejaksaan. Dengan peran aktif Jaksa penuntut umum dalam tindakan penyidikan makan maka perkara-perkara yang tidak ditindaklanjuti oleh penyidik dapat diambil alih jaksa, sebagaimana pada masa berlakunya HIR dan UU No. 15 Tahun 1961. Bahkan di banyak negara Jaksa juga diberi kewenangan melakukan penyidikan, walaupun secara faktual jaksa hampir tidak pernah melakukan sendiri penyidikan. Adanya kewenangan penyidikan lanjutan secara tidak langsung juga dapat dijadikan sebagai sarana kontrol, agar penyidik bersungguh-sungguh dalam menyidik suatu perkara, karena bila tidak sungguh-sungguh penyidikannya dapat diambil alih oleh Jaksa. Keberadaan penyidikan lanjutan oleh Jaksa juga dapat dijadikan sarana bagi pencari keadilan, khusunya korban atau pelapor, bila mereka tidak puas atas kinerja penyidik karena mendiamkan atau mengambangkan perkara yang dilaporkannya.

Di negara-negara yang sistem penuntutannya mengikuti tradisi Eropa Kontinental, dalam KUHAP-nya biasanya mencantumkan Jaksa sebagai salah satu penyidik. Bahkan dalam KUHAP Belanda jaksa ditempatkan sebagai penyidik pada urutan pertama, baru disusul penyidik -penyidik yang lainnya. Namun demikian, dalam pelaksanaan tugas sehari-harinya Jaksa hampir tidak pernah melakukan tugas penyidikan tetapi mensupervisi jalannya penyidikan yang dilakukan oleh penyidik. Ditetapkannya Jaksa sebagai penyidik salah satu tujuannya ialah agar Jaksa bisa melakukan penyidikan sendiri bila penyidik tidak menindaklanjuti laporan masyarakat. Dengan adanya kewenangan penyidikan yang dimiliki jaksa ini, penyidik menjadi sungguh-sungguh dalam melakukan penyidikan karena kalau 'bermain-main', percuma saja sebab perkaranya dapat diambil alih jaksa. Implikasinya penyidik menjadi professional sehingga Jaksa di Belanda hampir tidak pernah melakukan penyidikan.

Perluasan kewenangan pemeriksaan tambahan atau pun penghidupan kembali peran Jaksa dalam penyidikan sangat diperlukan agar tidak ada lagi kasus-kasus yang penyelesaiannya tidak jelas atau mengambang. Sebab dengan ketidakjelasan penyelesaian suatu perkara, hal tersebut sangat bertentangan dengan asas kepastian hukum dan dapat menimbulkan ketidakadilan karena merugikan pencari keadilan. Semua ini diperlukan agar tujuan akhir dari hukum acara pidana sebagaimana dikemukakan oleh Andi hamzah, yaitu mencapai ketertiban, ketentraman, kedamaian, keadilan dan kesejahteraan dalam masyarakat dapat terwujud dengan baik, sehingga cita-cita para pendiri bangsa sebagaimana tertuang dalam Pembukaan UUD 1945 dapat terpenuhi

Selanjutnya setelah penyempurnaan aturan (Substansi Hukum) dilakukan, sejalan dengan Teori Friedman maka maka kejaksaan harus menyiapkan sumber daya manusia (SDM) yang memiliki profesionalitas, integritas dan kualitas yang baik, khususnya di bidang penyidikan hal ini berkaitan dengan aspek struktur hukum. Sebab dengan peran aktif Jaksa dalam penyidikan maka perlu ada tambahan SDM 
yang memiliki keahlian, khususnya di bidang penyidikan, karena pada hakekatnnya substansi penyidikan, yaitu mengumpulkan alat bukti merupakan sub tugas yang sangat mendukung tugas penuntutan yang dilakukan oleh Jaksa.

\section{Simpulan}

1. Bahwa keterbatasan peran Penuntut umum dalam sistem peradilan pidana menurut KUHAP dapat terlihat dari tidak maksimalnya pengaturan mengenai prapenuntutan dalam norma positif KUHAP sehingga Jaksa tidak dapat mengikuti jalannya penyidikan secara obyektif dan substansial dan hanya memeriksa berkas perkara dari penyidik, yang mana hal tersebut menyulitkan penuntut umum untuk dapat aktif menjaga nilai-nilai Due Process of law yaitu mencegah terjadinya suatu pelanggaran/kesewenang-wenangan yang dilakukan oleh penyidik terhadap tersangka. Akibatnya dalam penyelesaian perkara pidana banyak ditemui kasus-kasus mengambang (floating case), selain itu dengan terbatasnya peran aktif Jaksa dalam penyidikan membuat Jaksa kesulitan dalam menjaga kualitas upaya penuntutan yang merupakan elemen penting dalam penyelesaian suatu perkara pidana, sehingga mengakibatkan putusan bebas yang dikarenakan kurang maksimalnya upaya penuntutan yang dilakukan Jaksa.

2. Bahwa salah satu upaya untuk penguatan peran penuntut umum dalam sistem sistem peradilan pidana di Indonesia adalah dengan memaksimalkan fungsi lembaga pemeriksaan tambahan sebagaimana diatur dalam Pasal 27 ayat (1) huruf d UU No. 5 Tahun 1991 dan tetap dipertahankan dalam UU No. 16 Tahun 2004 [Pasal 30 ayat (1) huruf e], kemudian selain itu diperlukan penyempurnaan substansi hukum dengan cara memasukkan ketentuan tentang peran aktif penuntut umum dalam tindakan penyidikan dalam hukum acara pidana (KUHAP) dan dalam UU Kejaksaan. Dengan peran aktif jaksa penuntut umum dalam tindakan penyidikan maka maka perkara-perkara yang tidak ditindaklanjuti oleh penyidik dapat diambil alih Jaksa, sebagaimana pada masa berlakunya $H I R$ sehingga asas kepastian hukum dan keadilan bagi para pencari keadilan dapat tercapai.

\section{E. Saran}

1. Diharapkan pihak-pihak yang terkait dengan penyusunan Undang-undang untuk memperhatikan perlunya penguatan fungsi dan peran penuntut umum dalam proses penyidikan, yang dapat dituangkan dalam RUU KUHAP atau perundang-undangan lain yang mengatur hukum acara pidana lainnya karena pada hakekatnya proses penyidikan merupakan bagian yang tidak terpisahkan dari proses penuntutan perkara pidana.

2. Kepada para penegak hukum baik Kepolisian, Kejaksaan, Pengadilan dan untuk meningkatkan sinergitas dan kerjasama yang solid dalam rangka menyelesaikan proses perkara pidana dengan mengedepankan nilai luhur keadilan, kepastian hukum dan kemanfaatan. 


\section{F. Daftar Pustaka}

\section{Buku}

Syaiful, Bakhri,. 2009. Hukum Pembuktian. Jakarta : Total Media.

Mahfud, Mannan.2012. Modul Pengantar Hukum Acara Pidana Diklat Pendahuluan Pendidikan dan pelatihan Pembentukan Jaksa. Jakarta : Badiklat Kejaksaan Republik Indonesia.

Daniel, Lev. S.1990.Hukum dan Politik di Indonesia Kesinambungan dan Perubahan (Penterjemah Nirwono dan AE Priyono) Jakarta : LP3ES.

Bismar, Siregar. 1983.Hukum Acara Pidana. Jakarta : Binacipta.

Hari, Sasangka.2007. Penyidikan, Penahanan, Penuntutan dan Praperadilan dalam Teori dan Praktek. Bandung : Mandar maju

M. Yahya Harahap.2003. Pembahasan Permasalahan dan Penerapan KUHAP Edisi Kedua. Jakarta : Sinar Grafika

\section{Makalah/Jurnal}

Andi Hamzah. Oktober 2014. “ Komentar Andi Hamzah”. Jurnal teropong MaPPI FHUI Volume 2. Jakarta : FHUI

Khunaifi Alhumami.2012 “ Makalah Peran lembaga pemeriksaan tambahan dalam penyelesaian perkara-perkara mengambang” Jakarta : Pusat Litbang Kejaksan Agung RI.

A.Z Abidin.2004."Makalah Usul perbaikan Kata dan Usul tambahan untuk memperkuat pendapat bahwa Kejaksaan Agung termasuk Jabatan Negara yang bersama-sama dengan Mahkamah Agung memegang Kekuasaan Kehakiman " Makassar : Pusat Litbang Kejaksan Agung RI.

\section{Perundang-undangan}

Undang-undang nomor 8 tahun 1981 tentang Undang-undang hukum Acara Pidana Indonesia

\section{Situs internet}

http://dedeandreas.blogspot.co.id/2015/03/teori-sistem-hukum-lawrence-m-friedman. html diakses pada 6 Januari 2017 pukul 22.00 WIB. 